\title{
Characterization of biofilm formation on a humic material
}

\author{
A. L. Rodrigues $\cdot$ A. G. Brito $\cdot$ P. Janknecht $\cdot$ \\ J. Silva $\cdot$ A. V. Machado $\cdot$ R. Nogueira
}

Received: 13 February 2008 / Accepted: 29 July 2008 / Published online: 20 August 2008

(C) Society for Industrial Microbiology 2008

\begin{abstract}
Biofilms are major sites of carbon cycling in streams. Therefore, it is crucial to improve knowledge about biofilms' structure and microbial composition to understand their contribution in the self-purification of surface water. The present work intends to study biofilm formation in the presence of humic substances (HSs) as a carbon source. Two biofilm flowcells were operated in parallel; one with synthetic stream water, displaying a background carbon concentration of $1.26 \pm 0.84 \mathrm{mg} \mathrm{L}^{-1}$, the other with added HSs and an overall carbon concentration of $9.68 \pm 1.00 \mathrm{mg} \mathrm{L}^{-1}$. From the biofilms' results of culturable and total countable cells, it can be concluded that the presence of HSs did not significantly enhance the biofilm cell density. However, the biofilm formed in the presence of HSs presented slightly higher values of volatile suspended solids (VSS) and protein. One possible explanation for this result is that HSs adsorbed to the polymeric matrix of the biofilm and were included in the quantification of VSS and protein. The microbial composition of the
\end{abstract}

A. L. Rodrigues · A. G. Brito $\cdot$ R. Nogueira $(\bowtie)$

Institute for Biotechnology and Bioengineering (IBB),

Centre of Biological Engineering, University of Minho,

Campus de Gualtar, 4700-057 Braga, Portugal

e-mail: regina@deb.uminho.pt

P. Janknecht

Stadtwerke Düsseldorf AG, Wasserwerke,

Himmelgeister Landstrasse 1, 40589 Düsseldorf, Germany

J. Silva

Centro de Recursos Microbiológicos (CREM),

Biotechnology Unit, Faculty of Sciences and Technology,

New University of Lisbon, 2829-516 Caparica, Portugal

A. V. Machado

Instituto de Polímeros e Compósitos (IPC),

University of Minho, 4800-058 Guimarães, Portugal biofilm with addition of HSs was characterized by the presence of bacteria belonging to beta-Proteobacteria, Cupriavidus metallidurans and several species of the genus Ralstonia were identified, and gamma-Proteobacteria, represented by Escherichia coli. In the biofilm formed without HSs addition beta-Proteobacteria, represented by the species Variovorax paradoxus, and bacteria belonging to the group Bacteroidetes were detected. In conclusion, the presence of HSs did not significantly enhance biofilm cell density but influenced the bacterial diversity in the biofilm.

Keywords Humic material · Biofilm · Flowcell · Community composition $\cdot$ FTIR

\section{Introduction}

Most of the microbial activity in streams resides in biofilms. Biofilms are microbial communities which have attached to surfaces and play key roles in carbon and nutrients cycling in streams $[1,2]$. High levels of natural organic matter (NOM) in surface water constitute a problem to the water industry because they are associated with the formation of carcinogenic disinfection by-products (e.g. trihalomethanes) upon chlorination of drinking water. Therefore, understanding the contribution of biofilms to regulate organic matter in water is important for the sustainable management of surface water resources. Moreover, stream biofilms might be exploited to improve surface water quality to be used in drinking water plants.

Humic substances (HSs) and non-humic substances correspond to the main categories of NOM. HSs result from microbial degradation of organic matter, possibly followed by reactions of polymerization, condensation, and oxidation. These reactions produce highly complex organic 
molecules [3]. HSs are mixtures, characterized by the presence of aromatic and aliphatic compounds with mainly carboxylic and phenolic functional groups [4]. HSs, particularly humic and fulvic acids, typically account for the majority (about $75 \%$ ) of the dissolved organic carbon (DOC) in river water [5]. Concentrations from 1 to $60 \mathrm{mg} \mathrm{L}^{-1}$ DOC are found in surface waters with typical values ranging from 2 to $10 \mathrm{mg} \mathrm{L}^{-1}$ [3]. The main DOC transformations occur in the riverbed [2]. Here, a complex assemblage of cells, mostly bacteria and fungi, embedded in a gelatinous matrix of extracellular polymeric substances (EPS) forms biofilms [1]. The EPS offer potential binding sites for a variety of inorganic and organic compounds [6] which can be taken up by microorganisms. The traditional model of dissolved organic matter (DOM) degradation assumes that simple organic molecules of low molecular weight (LMW) decompose faster than high molecular weight (HMW) compounds [7]. LMW compounds are less complex, thus they are considered more labile [7]. The more recent studies of Amon and Benner [8] suggest a new conceptual model whereby the bioreactivity of organic matter decreases along a continuum of both size (from large to small) and diagenetic state (from fresh to old). This sizereactivity continuum model suggests that the bulk of HMW DOM is more bioreactive and less diagenetically altered than the bulk of LMW DOM and that degradation of organic matter in aquatic environments leads to formation of refractory LMW compounds. Sun et al. [9] suggested that aliphatic carbon is the principal form of carbon being utilized by bacteria and that their ability to utilize DOM decreases as the aliphatic carbon content of the DOM decreases. In contrast with the "size-reactivity continuum model", the availability of DOC for bacteria is assumed to be controlled by the presence, abundance, and steric acces- sibility of specific chemical functional groups rather than by molecular size. Recently, the work of Fischer et al. [10] and Axmanovà et al. [11] also supported the hypothesis that certain fractions of DOC might be readily utilized for bacterial growth irrespective of molecular size depending on the presence and abundance of specific chemical groups.

Composition of bacterial communities growing on HSs is poorly documented in literature. In general, beta-Proteobacteria has been described as a dominant group in entrophic rivers $[12,13]$. Manz et al. [13] studied the composition of bacterial communities in mature river biofilms using fluorescence in situ hybridization and reported that alpha-Proteobacteria and the Bacteroidetes were prevalent over beta-Proteobacteria and gamma-Proteobacteria. In this context, the knowledge about the structure and function of biofilms growing on complex organic matter needs more consistent studies. In the present work, a model biofilm flowcell was developed to evaluate the contribution of HSs to biofilm and suspended growth under controlled hydrodynamic conditions.

\section{Materials and methods}

\section{Experimental system}

A biofilm flowcell system was designed to study biofilms growing under defined hydrodynamic conditions (Fig. 1). The media was recirculated from a mixing chamber to the flowcell and back. The cell was made of polyacrylic material with $0.042 \mathrm{~m}$ inner diameter and $1.04 \mathrm{~m}$ length, corresponding to a total submerged surface area of $0.14 \mathrm{~m}^{2}$. The flow velocity was maintained at $0.04 \mathrm{~m} \mathrm{~s}^{-1}$ (laminar regime, $\operatorname{Re}=1,669)$. Ten independently removable thermopolypropylene coupons $\left(\right.$ Matala $^{\mathrm{TM}}$ ) with $7.2 \mathrm{~cm}$ length,
Fig. 1 Schematic of experimental setup

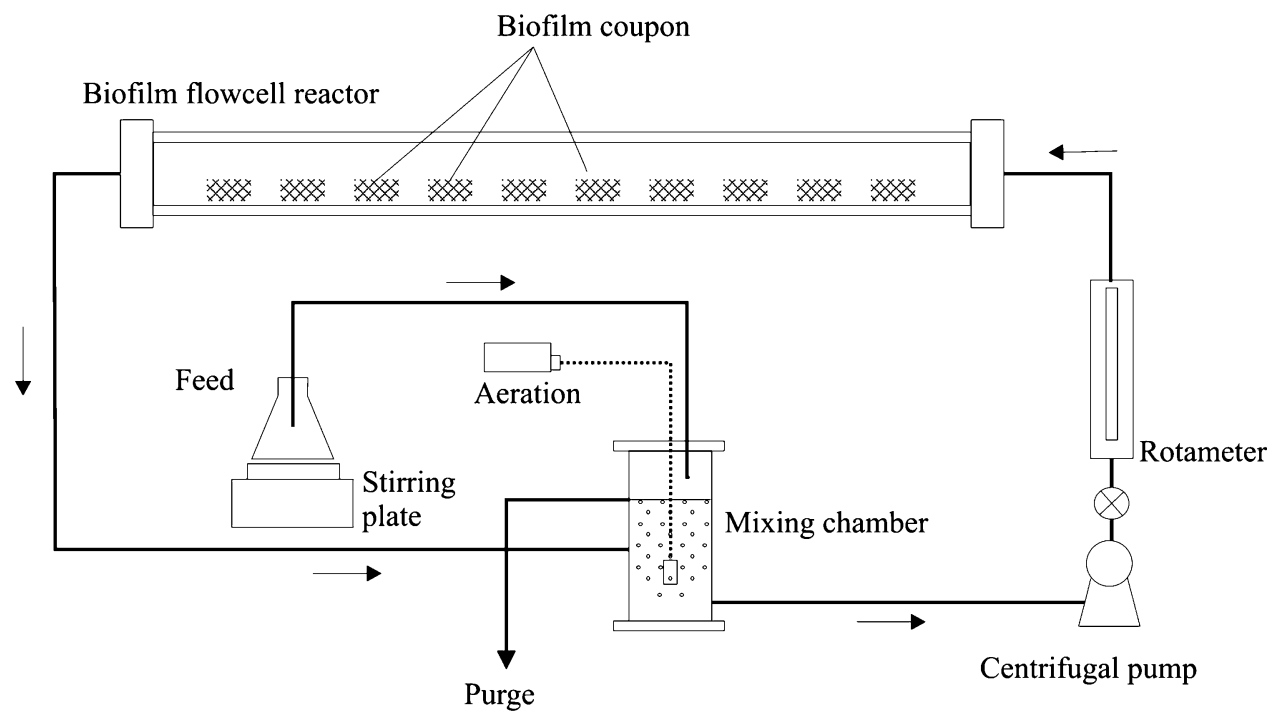


$2.5 \mathrm{~cm}$ width and $1 \mathrm{~cm}$ height in average were fitted in the cell, allowing for biofilm sampling. The coupons presented a highly porous tridimensional structure. The specific surface area of the material was $204 \mathrm{~m}^{2} \mathrm{~m}^{-3}$, yielding an average surface of $2.74 \times 10^{-4} \mathrm{~m}^{2}$ per coupon.

Media

The synthetic river water was composed of $0.06 \mathrm{mg} \mathrm{L}^{-1}$ $\mathrm{KH}_{2} \mathrm{PO}_{4}, 0.76 \mathrm{mg} \mathrm{L}^{-1} \mathrm{NH}_{4} \mathrm{Cl}, 0.67 \mathrm{mg} \mathrm{L}^{-1} \mathrm{KNO}_{3}, 23.51$ $\mathrm{mg} \mathrm{L}^{-1} \mathrm{MgSO}_{4} \cdot 7 \mathrm{H}_{2} \mathrm{O}, 19.54 \mathrm{mg} \mathrm{L}^{-1} \mathrm{CaCl}_{2} \cdot 2 \mathrm{H}_{2} \mathrm{O}, 27.60$ $\mathrm{mg} \mathrm{L}^{-1} \quad \mathrm{MgCl}_{2} \cdot 6 \mathrm{H}_{2} \mathrm{O}, \quad 20.94 \mathrm{mg} \mathrm{L}^{-1} \quad \mathrm{KCl}, \quad 1.88 \mathrm{mg} \mathrm{L}^{-1}$ $\left(\mathrm{NH}_{4}\right)_{2}\left[\mathrm{Fe}\left(\mathrm{SO}_{4}\right)_{2}\right] \cdot 6 \mathrm{H}_{2} \mathrm{O}, 3.87 \mu \mathrm{g} \mathrm{L}^{-1} \mathrm{ZnSO}_{4} \cdot 7 \mathrm{H}_{2} \mathrm{O}, 153.18$ $\mu \mathrm{g} \mathrm{L}^{-1} \mathrm{MnCl}_{2} \cdot \mathrm{H}_{2} \mathrm{O}, 3.18 \mu \mathrm{g} \mathrm{L}^{-1} \mathrm{CuSO}_{4} \cdot 5 \mathrm{H}_{2} \mathrm{O}, 0.14 \mathrm{ng} \mathrm{L}^{-1}$ $\mathrm{CoCl}_{2} \cdot 6 \mathrm{H}_{2} \mathrm{O}$, and $3.48 \mathrm{ng} \mathrm{L}^{-1} \mathrm{NiCl}_{2} \cdot 6 \mathrm{H}_{2} \mathrm{O}$ [14]. Humic substances (HSs), purchased from the International Humic Substances Society (IHSS), were extracted from Elliot Silt Loam Soil (BS102M) [15]. A concentrated stock solution was prepared by dissolving $100 \mathrm{~g}$ of HSs in $1 \mathrm{~L}$ of $\mathrm{NaOH}$ solution, $4 \mathrm{~g} \mathrm{~L}^{-1}$. This solution was mixed for $24 \mathrm{~h}$ and centrifuged at 5,000 rpm for $30 \mathrm{~min}$. The concentrated HSs stock solution $\left(1 \mathrm{~g} \mathrm{~L}^{-1}\right.$ of carbon) was stored in the dark at $4{ }^{\circ} \mathrm{C}[16]$. Distilled water was used in the preparation of all solutions.

\section{Experimental approach}

Two experiments were run in parallel under identical hydrodynamic conditions. The flowcell designated as test was fed with a humic material solution containing $9.68 \pm 1.00 \mathrm{mg} \mathrm{L}^{-1}$ of carbon, while the control was fed with a synthetic river water mineral solution without humic material. Experiments were performed in duplicate. The synthetic river water presented a background carbon concentration of $1.26 \pm 0.84 \mathrm{mg} \mathrm{L}^{-1}$, originating from the distilled water used in the preparation. The feed to both flowcells was supplied at a rate of $0.25 \mathrm{~mL} \mathrm{~min}{ }^{-1}$. Temperature was maintained at $20^{\circ} \mathrm{C}$ by means of cold water circulation in the water jacket around the flowcell and the $\mathrm{pH}$ was adjusted, with $2 \mathrm{M} \mathrm{NaCl}$ and $\mathrm{HCl}$ solutions to $7.0 \pm 0.2$. The values of the experimental parameters flow velocity, carbon concentration, temperature, and $\mathrm{pH}$ were chosen as $0.04 \mathrm{~m} \mathrm{~s}^{-1}, 10 \mathrm{mg} \mathrm{L}^{-1}, 20^{\circ} \mathrm{C}$, and 7.0 , respectively, because they are representative of environmental conditions in several streams [14, 17]. A microbial mixed culture from a sand filter treating surface river water (the water treatment plant from Braga, Portugal) was used as inoculum in both systems. Both flowcells were operated in the dark. During a period of 10 weeks, samples of biofilm and suspended biomass were collected weekly from both experiments and analyzed for volatile suspended solids (VSS), protein, culturable cells [namely, colony-forming unit (CFU)], and total countable cells (TC). Measurements were made in duplicate.

\section{Sampling}

The biofilm in the flowcells was sampled by removing a coupon and placing it aseptically into a falcon tube containing $40 \mathrm{~mL}$ of a sterile buffer solution (Ringer's solution). The tube was vigorously vortexed for $5 \mathrm{~min}$, sonicated for $15 \mathrm{~min}$ in a sonication bath (Model SC-52), and vortexed again for $5 \mathrm{~min}$. This procedure ensured maximum biofilm removal from the coupon. Subsequently the coupon was removed and the biofilm suspension was then homogenized for 20 min on ice using a tissuemizer with SBS-dispensing tool (model AV5). This procedure was indispensable for the subsequent cell enumeration after DAPI staining using an epifluorescence microscope. Suspension grab samples $(40 \mathrm{~mL})$ were taken aseptically in the recirculation tank and centrifuged at 4,500 rpm for $10 \mathrm{~min}$. The supernatant was rejected and the pellet was resuspended in $40 \mathrm{~mL}$ sterile buffer solution. The suspension was then subjected to a similar treatment as the biofilm suspension.

Analytical methods

\section{Total organic carbon (TOC)}

Total organic carbon (TOC) was measured spectrophotometrically at $600 \mathrm{~nm}$ using the Method 10129 from Hach Lange $\mathrm{GmbH}$. Organic carbon is oxidized with persulphate in the presence of acidic conditions and the carbon dioxide formed is captured by and indicator solution that changes color proportionally to the amount of organic carbon originally present in the sample. The results are expressed in $\mathrm{mg} \mathrm{L}{ }^{-1}$ of carbon.

\section{Biomass quantification}

Volatile suspended solids were measured according to the gravimetric method described in Standard methods [18]. Protein was measured according to the Lowry method [19], modified by Peterson [20], using the Sigma protein assay kit (Sigma Diagnostics, St Louis, MO, USA). Culturable cell counts were determined by spread plating $100 \mu \mathrm{L}$ of cell suspension on R2A agar medium and incubation at room temperature for 7 days. Samples for total cell counts, previously fixed with $40 \mathrm{~g} \mathrm{~L}^{-1}$ paraformaldehyde, were stained with 4,6-diamino-2-phenylindole (DAPI) $\left(0.25 \mathrm{mg} \mathrm{L}^{-1}\right)$ for $15 \mathrm{~min}$, filtered onto a black-stained polycarbonate filter (Nucleopore) with $2.27 \mathrm{~cm}^{2}$ of filtration surface area and rinsed with $5 \mathrm{~mL}$ of sterilized distilled water. Cell enumeration was carried out in an epifluorescence microscope (Zeiss, filter set $\mathrm{n}^{\circ} 01$, excitation $\lambda=372 \mathrm{~nm}$, emission $\lambda=456 \mathrm{~nm}$ ) at 1,000 fold magnification, a total of 20 fields was evaluated using a graduated grid divided into 346 squares $\left(1 \times 10^{-6} \mathrm{~cm}^{2}\right.$ each square $)$. 
The total surface area examined per sample was $1.8 \times 10^{-6} \mathrm{~cm}^{2}$ (20 fields times nine squares).

\section{Biofilm community characterization}

The composition of the bacterial community of 10-weekold biofilms was studied by 16S rRNA sequence analyses. Colonies from R2A plates presenting distinct morphologies and colors were selected and their purity was checked by successive plating in R2A plates. Subsequently the DNA was extracted and the 16S rRNA genes were amplified and sequenced. For DNA extraction, a loop of fresh cells was placed into a tube containing $20 \mu \mathrm{L}$ of alkaline lysis solution, composed of $0.25 \%$ sodium dodecyl sulphate (SDS) and $0.05 \mathrm{M} \mathrm{NaOH}$, and $180 \mu \mathrm{L}$ distilled water. The tube was vortexed for $1 \mathrm{~min}$ and then placed at $95^{\circ} \mathrm{C}$ for $5 \mathrm{~min}$. After $5 \mathrm{~min}$ centrifugation at $14,500 \mathrm{rpm}$, the pellet was discarded and the supernatant stored at $-20^{\circ} \mathrm{C}$ until use. $1 \mu \mathrm{L}$ of genomic DNA was used as template in a $25 \mu \mathrm{L}$ reaction mixture consisting of $0.8 \mu \mathrm{M}$ F8 (5'-AGA GTT TGA TCC TGG CTC AG-3') and R537 (5'-TAT TAC CGC GGC TGC TGG CA-3') primers (Fermentas), $200 \mu \mathrm{M}$ of each deoxynucleoside triphosphate, polymerase chain reaction (PCR) buffer $(2 \mathrm{mM} \mathrm{MgCl})$, and $0.04 \mathrm{U}$ of Taq polymerase (Fermentas). Thermal cycling was carried out with an initial denaturing step at $95^{\circ} \mathrm{C}$ for $5 \mathrm{~min}$, followed by 40 cycles of denaturation at $95^{\circ} \mathrm{C}$ for $30 \mathrm{~s}$, annealing at $55^{\circ} \mathrm{C}$ for $30 \mathrm{~s}$, and elongation at $72{ }^{\circ} \mathrm{C}$ for $45 \mathrm{~s}$; cycling was completed by a final elongation step at $72{ }^{\circ} \mathrm{C}$ for $10 \mathrm{~min}$. A negative control (no DNA added) was included in all sets of amplification. The presence and size of the amplification product was determined by agarose gel (1.2\%) electrophoresis of the reaction product $(5 \mu \mathrm{L})$. Ethidium bromide-stained bands were recorded with an Eagle Eye documentation system (Stratagene). Purification of the PCR product to remove excess primers and nucleotides was performed with shrimp alkaline phosphatase $\left(2.0 \mathrm{U} \mu \mathrm{L}^{-1}\right)$

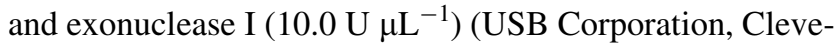
land, Ohio). Briefly, $1 \mu \mathrm{L}$ of each enzyme was added to $5 \mu \mathrm{L}$ of PCR product, the enzymes were activated for $15 \mathrm{~min}$ at $37^{\circ} \mathrm{C}$, followed by inactivation at $80^{\circ} \mathrm{C}$ for $15 \mathrm{~min}$. Cycle sequencing was performed using the Big Dye Terminator V3.1 Kit according to the manufacturer's protocol (Applied Biosystems). The labeled amplification product was analysed after removal of excess dyes on an ABI 310 Genetic analyzer (Applied Biosystems). The 16S rDNA sequences were assembled, edited, and compared to those in the GenBank. Sequences were aligned with MegAlign (DNASTAR Inc., Madison, WI, USA). Phylogenetic trees were computed with PAUP version $4.0 \mathrm{~b} 8$ (Sinauer Associates Inc., Sunderland, MA, USA) using the neighbor-joining method and the Kimura two-parameter model for calculating distances. Nucleotide sequences were deposited in GenBank under the accession numbers: EU330532 through EU330542. Gaps were treated as missing data. Additional sequences were retrieved from GenBank.

\section{Infrared spectroscopy}

Fourier transform infrared (FTIR) spectra of HSs and 10week-old biofilms formed with and without HSs were recorded with a ABB spectrometer (model FTLA 2000104) using a spectral range varying from 4,000 to $500 \mathrm{~cm}^{-1}$ and a resolution of four; a minimum of five scans per spectrum was performed. Biofilms were removed from the coupons, as previously described. The biofilm suspension was centrifuged and the resulting pellet was dried at $60^{\circ} \mathrm{C}$ and finely ground to powder [21, 22]. This procedure destroyed biofilms' structure. HSs were also dried at the same temperature. Twenty milligram of each biofilm powder and HSs were encapsulated in $200 \mathrm{mg}$ of $\mathrm{KBr}$ in order to prepare translucent sample disks used for FTIR analysis. Background correction for atmospheric air was used for each spectrum.

\section{Statistical analyses}

A $t$-test was used, where specific means were being compared. Acceptance or rejection of the null hypothesis was based on $\alpha$-level of 0.05 in all cases.

\section{Results and discussion}

Dynamics of biofilm and suspended biomass development

The effect of HSs on biofilm growth was studied using the parameters VSS, protein, culturable cells, and TC. The results are depicted in Fig. 2. The values of VSS and protein (panels A and B, respectively) were significantly higher ( $t$ test) in the biofilm formed in the presence of HSs than in their absence. However, the results of culturable and TC (panels $\mathrm{C}$ and $\mathrm{D}$, respectively) were not significantly different. In the presence of HSs $\left(9.68 \pm 1.00 \mathrm{mg} \mathrm{L}^{-1}\right.$ carbon), the culturable and total cell values obtained at the end of the experiment were $1.93 \times 10^{13}$ colony-forming unit $(\mathrm{CFU})$ and $2.06 \times 10^{13} \mathrm{TC} \mathrm{m}^{-2}$, respectively, while in the absence of HSs the values of the same parameters at the same time were of the same order of magnitude $1.15 \times 10^{13} \mathrm{CFU} \mathrm{m}{ }^{-2}$ and $1.50 \times 10^{13} \mathrm{TC} \mathrm{m}^{-2}$. One possible explanation for this result is that HSs adsorbed to the polymeric matrix of the biofilm and were included in the quantification of VSS and protein. In fact, in the presence of HSs a gradual darkening of the biofilm was observed (from light yellow to brown) which might be indicative of HSs adsorption. This hypothe- 
Fig. 2 Biofilm growth over 10 weeks. The SSV, protein, culturable, and total cells per square meter are presented in panels $A, B, C$ and $D$, respectively
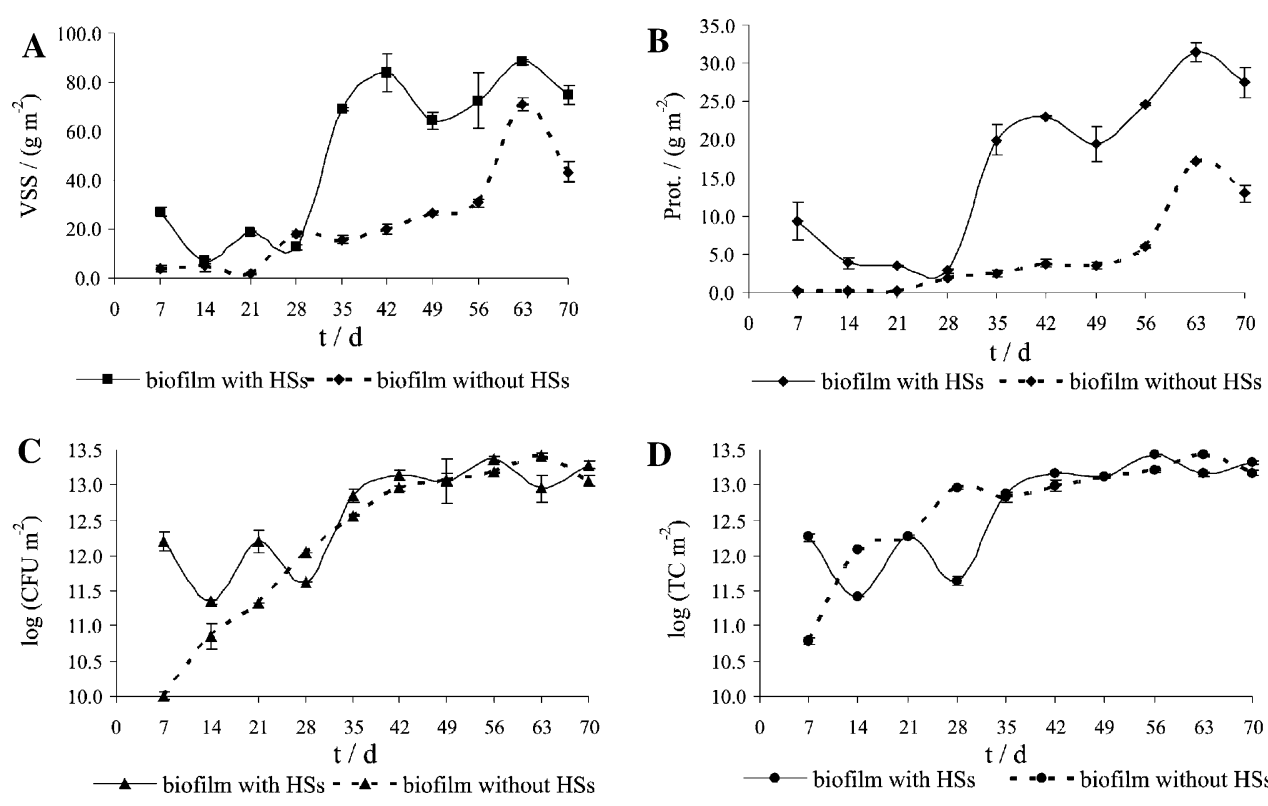

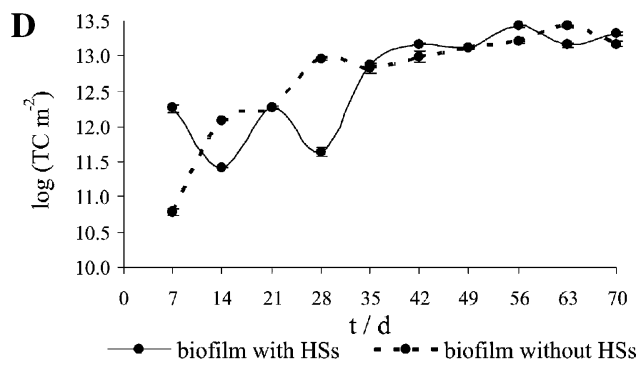

sis is supported by Fein [23] who reported the adsorption of HSs to the bacterial surface of a pure culture of Bacillus subtilis and by several other authors that described the adsorption of HSs to biofilms [24]. According to the results and the above discussion, it seems that biofilm growth was not significantly affected by the presence of HSs. The background carbon concentration derived from the distilled water without HSs addition contributed to the same amount of biofilm cell density as was observed in the presence of HSs. Few investigations have described the involvement of HSs in biofilm growth. Ellis et al. [16] studied biofilm formation in three different carbon sources and reported that the substrate that provided the highest biofilm total cell density was amino acids, followed by carbohydrates, and humics. Regarding the growth of suspended bacteria (Fig. 3), no significant changes ( $t$-test) were detected during the experimental lifetime. Thus biofilm formation, relatively to suspended bacteria, was enhanced by biological, physicochemical, and hydrodynamic experimental factors. This result is in agreement with those reported by Araya et al. [12] and Crump et al. [25], who found that respiring bacteria were higher in biofilms than in stream water samples.

As pointed out in several studies culturable cells might be a small fraction of the total number of cells in a sample
$[26,27]$. However, in the present work the numbers of TC were not significantly different from the culturable ones obtained either in the presence or absence of HSs. The culturability of bacteria in biofilms formed in the presence and absence of HSs was 94 and $77 \%$, respectively, obtained in the last week of the experiment. Similar high percentages of bacterial culturability are described in studies carried out with the R2A medium for mineral water (65\%, [28]) and sediment bacteria (82\%, [29]). This result might be explained by the fact that a nutrient poor media (R2A agar) was used for bacteria cultivation in combination with a low incubation temperature $\left(20^{\circ} \mathrm{C}\right)$ and an extended incubation time (7 days) [30].

\section{Characterization of HS and biofilm composition by FTIR}

To evaluate the presence of functional groups that might be assigned to HSs presence in the biofilm, the FTIR spectra of HSs and biofilms formed both in the presence and absence of HSs were determined (Fig. 4). A high number of absorption peaks reveal the complex nature of both HSs and biofilms. The most important features of HSs spectrum are: (1) a broad band at 3,600-3,200 $\mathrm{cm}^{-1}$, corresponding to $\mathrm{H}$-bonded $\mathrm{OH}$ groups as well as $\mathrm{H}-$ bonded $\mathrm{N}-\mathrm{H}$ groups,
Fig. 3 Suspended bacteria growth over 10 weeks. The suspended volatile solids and culturable cells are presented in panels $A$ and $B$, respectively
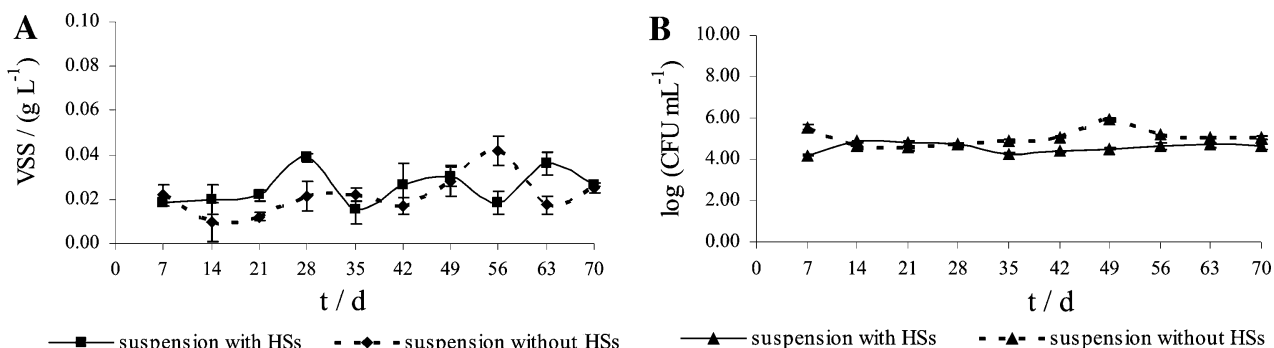


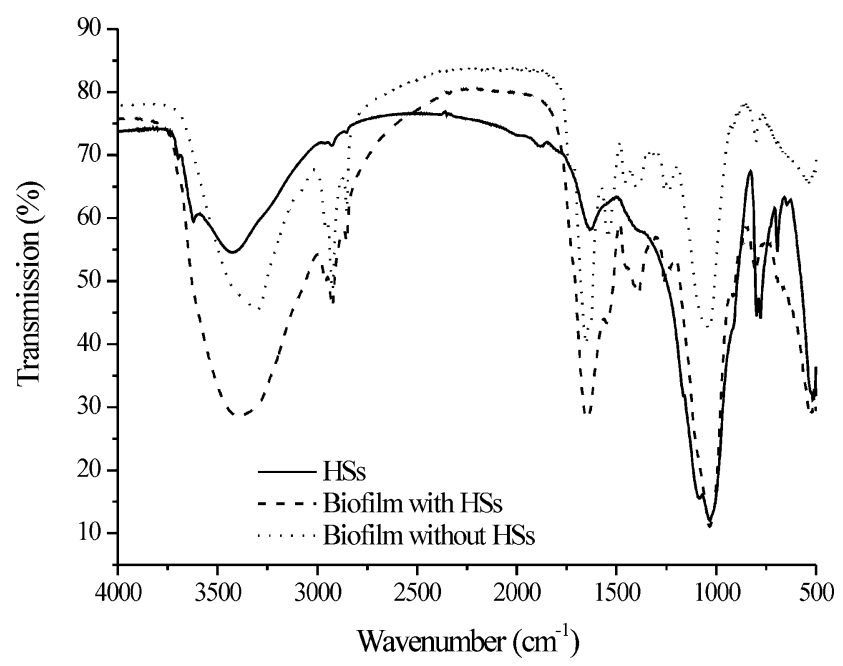

Fig. 4 FTIR spectra of humic material and both biofilms formed on the presence and absence of humic material

(2) a small peak at $2,920 \mathrm{~cm}^{-1}$, due to $\mathrm{C}-\mathrm{H}$ stretching of alkyl structures, (3) a peak at $1,628 \mathrm{~cm}^{-1}$, corresponding to carbonyl groups $\mathrm{C}=\mathrm{O}$ (e.g. amides), or stretching alkenes conjugated with or other double bonds $\mathrm{C}=\mathrm{C}$, and (4) a broad band at $1,120-990 \mathrm{~cm}^{-1}$ with a sharp peak at $1,031 \mathrm{~cm}^{-1}$, associated to $\mathrm{C}-\mathrm{O}$ stretching in polysaccharides and silicates. The presence of silicates is indicative of the soil nature of the HSs. The most important features of both biofilms' spectra are: (1) the large absorption band at $3,500-3,100 \mathrm{~cm}^{-1}$, resulting from $-\mathrm{OH}$ of hydroxyl groups $\left(\sim 3,400 \mathrm{~cm}^{-1}\right)$ and $\mathrm{N}-\mathrm{H}$ stretching modes (amide A $\left.\sim 3,300 \mathrm{~cm}^{-1}\right)$, (2) the region between 3,000 and $2,800 \mathrm{~cm}^{-1}$, showing the $\mathrm{C}-\mathrm{H}$ stretching vibrations of $-\mathrm{CH}_{3},-\mathrm{CH}_{2}$ and $-\mathrm{CH}$ functional groups, which are characteristics of fatty acid chains of the various membrane amphiphiles (e.g. phospholipids) and of some amino acid side-chain groups, and (3) the region between 1,800$1,500 \mathrm{~cm}^{-1}$, associated with amide bands, $\mathrm{C}=\mathrm{O}, \mathrm{C}-\mathrm{N}$, and $\mathrm{C}=\mathrm{C}$ stretching of the DNA or RNA heterocyclic base structures. A complex absorption can be observed between 1,500 and $1,300 \mathrm{~cm}^{-1}$, arising mainly from $\mathrm{CH}-\mathrm{CH}_{2}$ and $-\mathrm{CH}_{3}$ bending modes of lipids and proteins. The spectral region between 1,200 and $900 \mathrm{~cm}^{-1}$ is generally dominated by the symmetric stretching vibration of $\mathrm{PO}_{2}{ }^{-}$groups in nucleic acids and by a complex sequence of peaks associated with $\mathrm{C}-\mathrm{O}-\mathrm{C}$ and $\mathrm{C}-\mathrm{O}-\mathrm{P}$ stretching vibrations of various oligo- and polysaccharides [31]. The spectrum of the biofilm formed with HSs shows differences in certain peaks relatively to the spectrum of the biofilm without HSs, namely in the region of $3,500-3,100 \mathrm{~cm}^{-1}$ (the signal at $3,380 \mathrm{~cm}^{-1}$ became less pronounced), between 1,800 and $1,400 \mathrm{~cm}^{-1}$ (peaks at $1,742,1,548$ and $1,459 \mathrm{~cm}^{-1}$ almost disappear), and in the region of $1,200-900 \mathrm{~cm}^{-1}$ (a new peak appears at $909 \mathrm{~cm}^{-1}$ ). These differences observed between the two spectra, i.e., decrease of peaks' intensity and appearance of new peaks indicate changes in functional groups which might be related to the presence of HSs in the biofilm. Since FTIR analysis was performed in dehydrated and highly disrupted biofilms, differences between spectra cannot corroborate the hypothesis formulated previously concerning HSs adsorption to the biofilm.

\section{Biofilm microbial composition}

The biofilm community composition was based upon only those microorganisms that were culturable. The main reason to have chosen a cultivation-dependent method was related to the high percentage of bacterial culturability obtained in the present study. In the biofilm formed with HSs, evaluation of the microbial community composition by the $16 \mathrm{~S}$ rRNA approach revealed the presence of bacteria belonging to the subclasses beta-Proteobacteria, Cupriavidus metallidurans and several species of the genus Ralstonia were identified, as well as gamma-Proteobacteria represented by Escherichia coli. A phylogenetic tree including all sequenced species is given in Fig. 5. Beta-Proteobacteria are common in aquatic ecosystems [12], drinking water biofilms [32], and soil [33]. The HSs used in the present study, extracted from Elliot Silt Loam Soil (IHSS), enhanced the growth of bacteria from the genus Cupriavidus and Ralstonia that are common in soil.

In the biofilm formed without HSs, the presence of beta subclass-Proteobacteria, represented by the species Variovorax paradoxus, and bacteria belonging to the group Bacteroidetes was detected. The genus Variovorax is common in soil and water environments and the group Bacteroidetes are well known to degrade complex macromolecules [34]. Noble et al. [35] reported that members of the group Bacteroidetes are adapted to low nutrient and substrate concentrations. Geller [36] found that Flavobacterium isolated from lake water decompose refractory substrates more efficiently than other strains. Further research in biofilms formed on HSs should be carried out to establish a relationship between the structure and the function of the microbial communities [37]. Culture-dependent and independent methods used to assess microbial diversity in the same sample have been shown to produce distinct results [38]. Thus the presence and abundance of the retrieved sequences within the cells present in the original environmental sample should be estimated by hybridization with nucleic acid probes.

\section{Conclusions}

The results of the flowcell operated with HSs and without HSs $\left(9.68 \pm 1.00 \mathrm{mg} \mathrm{L}^{-1}\right.$ and $1.26 \pm 0.84 \mathrm{mg} \mathrm{L}^{-1}$ carbon concentration, respectively), at flow velocity of $0.04 \mathrm{~m} \mathrm{~s}^{-1}$ 
Fig. 5 Phylogenetic tree of representative isolates and of selected species of bacteria obtained by neighbor-joining analysis of $16 \mathrm{~S}$ rRNA gene, partial sequence, using PAUP 4.0b8. The numbers given on the branches are the frequencies ( $>50 \%)$ with which a given branch appeared in 1,000 bootstrap replications. Aquifex pyrophilus was used as outgroup. Sequences determined by the authors of the present study are typed in boldface. Additional sequences were retrieved from GenBank (species names followed by the corresponding accession number between parentheses)

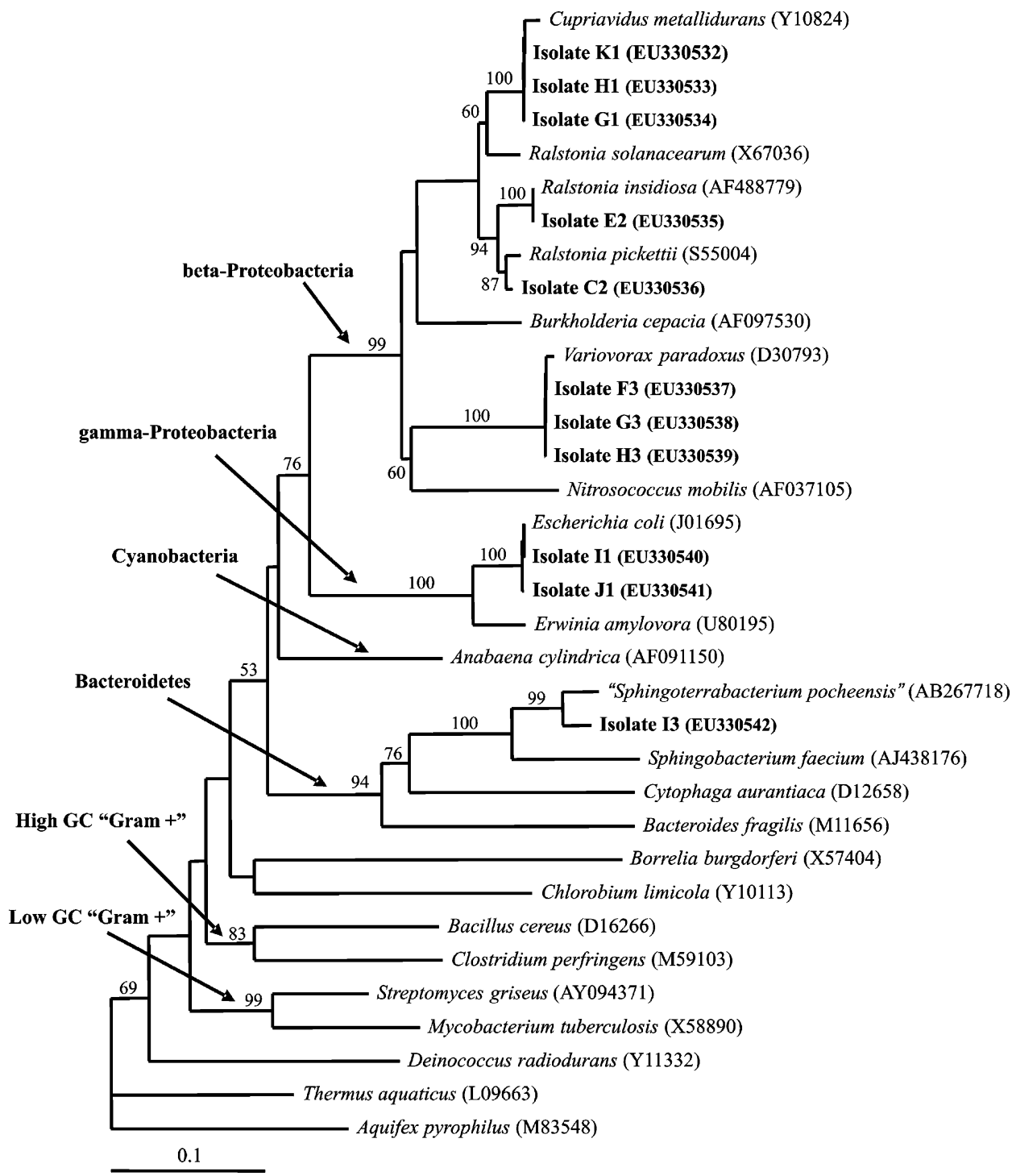

and $20^{\circ} \mathrm{C}$, do not indicate positive effects of the presence of humic material on biofilm cell density. Investigations will be carried out to establish the nature and magnitude of biofilm response to specific controlled changes in stream conditions specifically flow velocity, DOC, and oxygen.

The presence of HSs, however, did influence biofilm microbial composition: biofilm formed in the presence of HSs was characterized by the occurrence of beta-Proteobacteria belonging to the genus Cupriavidus and Ralstonia, while the presence of beta-Proteobacteria belonging to the genus Cupriavidus and Bacteriodetes were found in the biofilm formed in the absence of HSs.

Acknowledgements The work described in this paper was financially supported by FCT-Foundation for Science and Technology (Portugal) - by the PhD student grant SFRH/BD/18565/2004. This support is gratefully acknowledged. The authors would also thank to Mr. Marc Talloen for supplying the thermo-polypropylene material Matala $^{\mathrm{TM}}$.

\section{References}

1. Lock MA (1993) Attached microbial communities in rivers. In: Ford TE (ed) Aquatic microbiology. Blackwell, Oxford, pp 113138

2. Dahm CN (1981) Pathways and mechanisms for removal of dissolved organic carbon from leaf leachate in streams. Can J Aquatic Sci 38:68-76

3. Beckett R (1990) The surface chemistry of humic substances in aquatic systems. In: Beckett R (ed) Surface and colloid chemistry in natural waters and water treatment. Plenum, New York, pp 3-16

4. Thurman EM (1985) Organic geochemistry of natural waters. Martinus Nijhoff/Dr W Junk Publishers, Dordrecht

5. Barreto SRG, Nozaki J, Barreto WJ (2003) Origin of dissolved organic carbon studied by UV-vis spectroscopy. Acta Hydroch Hydrob 31(6):513-518

6. Flemming H-C (1995) Sorption Sites in Biofilms. Water Sci Technol 32(8):23-33

7. Saunders GW (1976) Decomposition in fresh water. In: Anderson J, MacFadyen A (eds) The role of terrestrial and aquatic organisms in decomposition process. Blackwell, London 
8. Amon RMW, Benner R (1996) Bacterial utilization of different size classes of dissolved organic matter. Limnol Oceonogr 41:41-51

9. Sun L, Perdue EM, Meyer JL, Weis J (1997) Use of elemental composition to predict bioavailability of dissolved organic matter in a Georgia river. Limnol Oceonogr 42:714-721

10. Fischer H, Sachse A, Steinberg CEW, Push M (2002) Differential retention and utilization of dissolved organic carbon by bacteria in river sediments. Limnol Oceonogr 47:1702-1711

11. Axmanovà Š, Kountný J, Cupalová J, Rulík M (2006) Bacterial growth and community composition in fractions of dissolved organic carbon of different molar mass from interstitial water. Folia Microbiol 51(5):439-444

12. Araya R, Tatsuya T, Nobuyasu Y, Masao N (2003) Bacterial activity and community composition in stream water and biofilm from an urban river determined by fluorescent in situ hybridization and DGGE analysis. FEMS Microbiol Ecol 43:111-119

13. Manz W, Potthoff KW, Neu TR, Szewzyk U, Lawrence JR (1999) Phylogenetic composition, spatial structure, and dynamics of lotic bacterial biofilms investigated by fluorescent in situ hybridization and confocal laser scanning microscopy. Microbial Ecol 37:225237

14. Markich SJ, Brown PL (1998) Relative importance of natural and anthropogenic influences on the fresh surface water chemistry of the Hawkesbury-Nepean River, south-eastern Australia. Sci Total Environ 217:201-230

15. Swift RS (1996) Organic matter characterization. In: Sparks DL et al (eds) Methods of soil analysis. Part 3. Chemical methods, vol chap 35. , Soil Sci. Soc. Am. Book Series: 5Soil Science Society of Amerrica, Madison, pp 1018-1020

16. Ellis B, Butterfield P, Jones WL, McFeters GA, Camper AK (2000) Effects of carbon source, carbon concentration, and chlorination on growth related parameters of heterotrophic biofilm bacteria. Microbial Ecol 38:330-347

17. Tank JL, Dodds WK (2003) Nutrient limitation of epilithic and epixylic biofilms in ten North American streams. Freshwater Biol 48:1031-1049

18. APHA AWWA, CF WP (1998) Standard methods for the examination of water and wastewater, 20th edn. American Public Health Association, Washington DC

19. Lowry OH, Rosebrough NJ, Farr AL, Randall RJ (1951) Protein measurement with folin phenol reagent. J Biol Chem 193:265-275

20. Peterson GL (1977) A simplification of the protein assay method of Lowry et al. which is more generally applicable. Anal Biochem 83:346-356

21. Quintelas C, Fernandes B, Castro J, Figueiredo H, Tavares T (2008) Biosorption of $\mathrm{Cr}(\mathrm{VI})$ by a Bacillus coagulans biofilm supported on granular activated carbon (GAC). Chem Eng J 136:195-203

22. Ramesh A, Lee D-J, Hong SG (2006) Soluble microbial products (SMP) and soluble extracellular polymeric substances (EPS) from wastewater sludge. Appl Microbiol Biotechnol 73:219-225

23. Fein JB, Boily JF, Güçlü K, Kaulbach E (1999) Experimental study of humic acid adsorption onto bacteria and Al-oxide mineral surfaces. Chem Geol 162:33-45
24. Battin TJ, Butturini A, Sabater F (1999) Immobilization and metabolism of dissolved organic carbon by natural sediment biofilms in a Mediterranean and temperate stream. Aquat Microb Ecol 19:297-305

25. Crump BC, Armbrust EV, Baroos JA (1999) Phylogenetic analysis of particle-attached and free-living bacterial communities in the Columbia river, its estuary, and the adjacent coastal ocean. Appl Environ Microb 65(7):3192-3204

26. Kisand V, Cuadros R, Wikner J (2002) Phylogeny of culturable estuarine bacteria catabolizing riverine organic matter in the Northern Baltic Sea. Appl Environ Microb 68(1):379-388

27. Simu K, Holmfeldt K, Zweifel UL, Hagström $\AA$ (2005) Culturability and coexistence of colony-forming and single-cell marine bacterioplankton. Appl Environ Microb 71(8):4793-4800

28. Defives C, Guyard S, Oularé MM, Mary P, Hornez JP (1999) Total counts, culturable and viable, and non-culturable microflora of a French mineral water: a case study. J Appl Microbiol 86:10331038

29. Foght J, Aislabie J, Turner S, Brown CE, Ryburn J, Saul DJ, Lawson W (2004) Culturable bacteria in subglacial sediments and ice from two southern hemisphere glaciers. Microbial Ecol 47:329340

30. Reasoner DJ (2004) Heterotrophic plate count methodology en the United States. Int J Food Microbiol 92:307-315

31. Naumann D (2000) Infrared spectroscopy in microbiology. In: Meyers RA (ed) Encyclopedia of analytical chemistry. Wiley, Chichester, pp 102-131

32. Schmeisser C, Stöckigt C, Raasch C, Wingender J, Timmis KN, Wenderoth DF, Flemming H-C, Liesegang H, Schmitz RA, Jaeger K-E, Streit WR (2003) Metagenome survey of biofilms in drinking-water networks. Appl Environ Microb 69(12):7298-7309

33. Chang Y-T, Lee J-F, Chao H-P (2007) Variability of communities and physiological characteristics between free-living bacteria and attached bacteria during the PAH biodegradation in a soil/water system. Eur J Soil Biol 43:283-296

34. Kojima H, Koizumi Y, Fukui M (2006) Community structure of bacteria associated with seaths of freshwater and brackish thioploca species. Microbial Ecol 52:765-773

35. Noble PA, Dabinett PE, Crow J (1990) A numerical taxonomic study of pelagic and benthic surface-layer bacteria in seasonallycold coastal waters. Syst Appl Microbiol 13:77-85

36. Geller A (1986) Comparision of mechanisms enhancing biodegradability of refractory lake water constituents. Limnol Oceonogr 31(4):755-764

37. Romaní AM, Guash H, Muñoz I, Ruana J, Vilalta E, Schwartz T, Sabater FS (2004) Biofilm structure and function and possible implications for riverine DOC dynamics. Microbial Ecol 47:316328

38. Tamaki H, Sekiguchi Y, Hanada S, Nakamura K, Nomura N, Matsumura M, Kamagata Y (2005) Comparative analysis of bacterial diversity in freshwater sediment of a shallow eutrophic lake by molecular and improved cultivation-based techniques. Appl Environ Microbiol 71(4):2162-2169 